\title{
DISCLOSURE ATAS MANAGEMENT STATEMENT, INTELLECTUAL CAPITAL, DAN CORPORATE SOCIAL RESPONSIBILITY TERHADAP NILAI PERUSAHAAN
}

\begin{abstract}
Value of the firm is an investor perception about the condition of the firm, which is often refered to the stock price. High stock prices indicate high public appreciation of the firm. Efforts to maximize value of the firm is done by maximizing the factors that influence it. This study used three variables, namely Statement Management Disclosure, Intellectual Capital Disclosure, and Corporate Social Responsibility Disclosure. The object of the research is manufacturing company from 2009 to 2013. Samples were collected by purposive sampling method. Multiple linear regression model used in this research model testing. The results showed that CSR Disclosure had a positive effect on Firm Value. Intellectual Capital Disclosure does not affect the Firm Value, while Management Statement Disclosure had a negative effect on the Firm Value.
\end{abstract}

Keywords: Management Statement Disclosure, Intellectual Capital Disclosure, Corporate Social Responsibility Disclosure, Firm Value

\section{PENDAHULUAN}

Dalam era globalisasi ini persaingan bisnis menjadi sangat kuat, baik di pasar domestik maupun di pasar internasional. Globalisasi, inovasi, teknologi, dan persaingan yang ketat tersebut memaksa perusahaanperusahaan untuk mengubah cara mereka dalam menggerakkan usahanya. Dengan adanya perdagangan bebas seperti APEC (The Asia Pacific Economic Cooperation), NAFTA (North America Free Trade Area), AFTA (Asian Free Trade Area), maupun AEC (Asean Economic Community) menimbulkan efek double yaitu tidak hanya membuka kesempatan kerja sama antarnegara, namun sekaligus juga merupakan ancaman bagi negaranegara, terkait dengan persaingan yang lebih ketat.

Salah satu tujuan penting pendirian suatu perusahaan adalah untuk meningkatkan kesejahteraan pemiliknya atau pemegang saham, atau memaksimalkan kekayaan pemegang saham melalui peningkatan nilai perusahaan (Bringham dan Houston, 2001). Peningkatan nilai perusahaan tersebut dapat terwujud jika perusahaan mampu beroperasi dengan mencapai laba yang dianggarkan. Melalui laba yang diperoleh tersebut, perusahaan akan mampu membagikan deviden kepada pemegang saham, meningkatkan pertumbuhan perusahaan, melebarkan investasi, serta mempertahankan kelangsungan hidupnya.

Nilai perusahaan merupakan persepsi investor terhadap kondisi perusahaan, yang sering mengacu pada harga saham. Harga saham yang tinggi menunjukkan apresiasi masyarakat terhadap perusahaan juga tinggi. Tujuan utama perusahaan adalah untuk meningkatkan kemakmuran pemilik perusahaan dengan memaksimumkan kekayaan atau nilai perusahaan, Theory of the Firm (Salvatore, 2005). Memaksimalkan nilai perusahaan sangat penting artinya bagi suatu perusahaan, karena dengan memaksimalkan nilai perusahaan berarti juga memaksimalkan kemakmuran pemegang saham yang merupakan tujuan utama perusahaan. 
Nilai perusahaan merupakan harga yang bersedia dibayar oleh calon pembeli jika perusahaan tersebut dijual (Husnan, 2004). Nilai perusahaan merupakan nilai pasar atas surat berharga hutang dan ekuitas perusahaan yang beredar (Keown, 2004). Kekayaan pemegang saham dan perusahaan dipresentasikan oleh harga pasar dari saham yang merupakan cerminan dari keputusan investasi, pendanaan, dan manajemen aset (Bringham, E.F, 1996).

Profesionalisme manajemen menjadi sorotan tajam, sehingga manajemen cenderung mematuhi untuk bertindak profesional. Efeknya adalah pernyataan dari manajemen yang berupa laporan manajemen (Management Statement/MS) dapat dianggap sebagai informasi yang cukup kompeten untuk dasar pertimbangan pengambilan keputusan oleh para investor. Beberapa negara sudah mengharuskan manajemen untuk membuat laporan perkiraan dan perencanaan seperti itu. Hal tersebut masuk dalam komponen item pelaporan keuangan yang bersifat mandatory. Seperti negara Belanda, Perancis, dan Inggris sudah mengharuskan perusahaan untuk membuat Laporan Direktur. Amerika Serikat dan Jerman sudah mengharuskan membuat Laporan Manajemen. Sedangkan di Asia, negara Jepang sudah mengharuskan perusahaan yang listing untuk membuat proposal penggunaan laba ditahan dan skedul pendukungnya (Choi, 2012).

Dalam rangka mempertahankan bisnisnya agar mampu bersaing, maka perusahaan- perusahaan harus mengubah mind set usahanya dari yang berbasis tenaga kerja menjadi berbasis pengetahuan (Knowledge Based View). Perusahaan yang berbasis pada pengetahuan akan mengelola pengetahuan untuk dijadikan landasan dalam setiap langkah menjalankan bisnisnya. Seiring dengan perubahan ekonomi yang memiliki karakteristik ekonomi berbasis pengetahuan, maka kemakmuran suatu perusahaan akan bergantung pada suatu penciptaan transformasi dan kapitalisasi pengetahuan itu sendiri (Sawarjuwono, 2003).

Transformasi dan kapitalisasi pengetahuan ini tercermin pada terdapatnya pengakuan bahwa selain modal fisik ternyata terdapat modal yang tidak dapat diukur langsung yang berbasis pengetahuan yang melekat pada sumber daya manusia yang merupakan modal bagi manajemen perusahaan untuk mengelola perusahaan. Modal seperti ini kemudian disebut sebagai Intellectual Capital/IC. Pada laporan keuangan yang belum konvergensi dengan IFRS (sebelum 2012), sangat terlihat jelas pada perbedaan nilai buku dengan nilai pasar, dimana menunjukkan adanya selisih atau nilai yang hilang, atau nilai yang tidak berwujud dari aset fisik perusahaan. Kenyataan ini menunjukkan bahwa pasar tidak hanya menilai perusahaan dari apa yang disajikan di Laporan Posisi Keuangan saja. Adanya selisih antara nilai buku dan nilai pasar ini mengindikasikan adanya sumber daya lain yang tersembunyi, yang menjadi sumber penilaian lain bagi perusahaan yang tidak dicantumkan di Laporan Posisi Keuangan secara eksplisit. Hal ini terjadi karena adanya intangible asset yang tidak tersajikan di dalam laporan keuangan. Atau tersajikan namun dianggap sebagai goodwill walaupun sebenarnya keduanya merupakan hal yang berbeda (SAK, 2012).

Keterbatasan laporan keuangan dalam menjelaskan nilai perusahaan menunjukkan bahwa sumber daya ekonomi perusahaan sudah bukan lagi berupa sumber daya fisik, namun sudah berwujud penciptaan intellectual capital (Chen, 2005). Intellectual capital didefinisikan sebagai informasi dan pengetahuan yang diaplikasikan dalam pekerjaan untuk menciptakan nilai (Williams, 2001). Komponen intellectual capital berupa

Jurnal Akuntansi Indonesia 
physical capital, human capital, dan structural capital.

Semakin baik intellectual capital suatu perusahaan menunjukkan bahwa perusahaan mampu bersaing dengan pesaing bisnisnya dengan mengandalkan pengetahuan dalam mengelola perusahaan, mampu mengelola sumber daya manusianya, mampu mengelola aset fisiknya, dan mampu mengelola proses internal perusahaan dengan baik. Akibatnya kondisi keuangan perusahaan akan membaik, yang ditunjukkan dengan perbaikan rasio-rasio keuangan perusahaan. Dengan demikian kinerja keuangan yang merupakan salah satu pengukur kinerja perusahaan akan membaik pula.

Berkaitan dengan sustainability perusahaan, sangatlah penting bagi manajemen untuk terus menjaganya. Salah satu cara adalah menggunakan dukungan penuh dari para stakeholder termasuk didalamnya pihak-pihak dalam lingkup lingkungan perusahaan maupun berbagai pihak di luar lingkup lingkungan perusahaan. Agar perusahaan memperoleh dukungan tersebut, maka ada strategi yang cukup mendasar, yaitu dengan melakukan kegiatan-kegiatan diluar usaha dalam memperoleh profit perusahaan sebagai bentuk pertanggungjawaban perusahaan yang juga turut memperhatikan kesejahteraan maupun keselamatan di lingkup yang termasuk dalam lingkungan perusahaan. Tanggung jawab sosial merupakan bentuk tanggung jawab perusahaan terhadap sosial atau terhadap seluruh lingkungan perusahaan. Termasuk di dalam lingkungan perusahaan disini adalah mulai dari lingkungan internal, meliputi tenaga kerja yang berada di bawah badan serikat pekerja, konsumen, lingkungan masyarakat sekitar, dan lingkungan alam sekitar.

Corporate social responsibility timbul sejak munculnya kesadaran bahwa keberlanjutan usaha di masa yang akan datang dalam jangka panjang adalah lebih penting daripada hanya usaha memperoleh profit yang kecenderungannya merupakan pemikiran jangka pendek saja, (Juniarti, 2009). Di Indonesia peraturan mengenai corporate social responsibility ada di UU No. 25 Tahun 2007 tentang Penanaman Modal. Dengan adanya peraturan tersebut menunjukkan bahwa corporate social responsibility sudah merupakan kegiatan wajib dan bukan sekedar kegiatan yang bersifat sukarela saja. Adapun kegiatannya dapat berupa pemberian kesempatan kerja bagi masyarakat sekitar, pengelolaan limbah produksi dengan menggunakan analisis dampak lingkungan yang sudah terstandar, ikut serta dalam pemeliharaan kelestarian alam lingkungan sekitar, ikut serta dalam pembangunan dan pengembangan infrastruktur dan fasilitas publik di daerah berdirinya perusahaan, pembuatan kemasan makanan yang bersifat "go green", pemberian beasiswa pada masyarakat yang membutuhkan serta turut mengembangkan perekonomian dimana perusahaan tersebut berdiri.

Konsep corporate social responsibility melibatkan tanggung jawab kemitraan bersama antara perusahaan, pemerintah, lembaga sumber daya masyarakat, serta masyarakat komunitas setempat. Pengungkapan tanggung jawab sosial perusahaan merupakan proses pengkomunikasian dampak sosial dan lingkungan dari kegiatan ekonomi perusahaan terhadap masyarakat (Rustriarini, 2010). Pengungkapan tanggung tanggung jawab sosial dapat menjadi strategi perusahaan dalam meningkatkan kinerja keuangan dan selanjutnya meningkatkan nilai perusahaan di mata masyarakat. Jika banyak informasi yang diungkapkan, berarti sudah banyak kegiatan sosial yang dilakukan oleh perusahaan. Para stakeholder akan melihat laporannya berupa beban di Laporan Laba Rugi Komprehensif ataupun di Catatan atas Laporan Keuangan. Investor dan calon investor sebagai salah satu pihak pengevaluasi kinerja perusahaan akan menggunakan informasi ini sebagai 
bahan pertimbangan dalam mengucurkan dananya bagi perusahaan. Jika hasil evaluasi baik, maka dana akan diperoleh, kegiatan operasi maupun pendanaan akan semakin lancar dan efek berikutnya adalah kinerja keuangan semakin baik. Efek terakhir adalah apresiasi masyarakat dengan adanya kinerja keuangan yang baik, maka akan meningkatkan nilai perusahaan yang tercermin di harga saham perusahaan.

Semakin pentingnya sustainability bagi suatu perusahaan agar dapat terus going concern dibuktikan dengan munculnya Laporan Keberlanjutan (Sustainability Report). Laporan ini mulai diterbitkan oleh berbagai perusahaan di luar Laporan Tahunan (Annual Report). Keberadaan laporan ini semakin diperhatikan oleh para stakeholder sehingga mendorong National Center for Sustainability Reporting (NCSR) mengadakan penilaian terhadap laporan tersebut secara tahunan yang diikuti oleh berbagai perusahaan, termasuk perusahaanperusahaan non publik. NCSR merupakan organisasi independen yang mempromosikan dan mengembangkan sistem laporan keberlanjutan di Indonesia melalui training yang diakreditasi oleh Global Reporting Initiative (GRI). GRI sendiri merupakan sebuah jaringan berbasis organisasi yang telah mempelopori perkembangan dunia, paling banyak menggunakan kerangka laporan keberlanjutan dan berkomitmen untuk terus-menerus melakukan perbaikan dan penerapan di seluruh dunia. Saat ini pedoman laporan keberlanjutan terbaru yang dikeluarkan oleh GRI adalah GRI G4 yang menekankan pada konsep materialitas. GRI G4 dirilis tahun 2013 dan sudah banyak perusahaan yang mengacu pada pedoman tersebut.

Pengungkapan informasi dari ketiga hal tersebut di atas, yaitu Management Statement (MS), Intellectual Capital (IC), dan Corporate Social Responsibility (CSR), menjadi suatu kebutuhan bagi investor. Oleh karenanya berdasarkan faktor kebutuhan tersebut dan beberapa hasil penelitian sebelumnya, maka penelitian ini dilakukan dengan menggunakan tiga variabel independen, yaitu MS Disclosure (MSD), IC Disclosure (ICD), dan CSR Disclosure (CSRD), menguji pengaruhnya terhadap Price Earnings Ratio (PER) yang merupakan indikator dari nilai perusahaan berdasar persepsi pasar

\section{KAJIAN PUSTAKA}

\section{Knowledge-Based View (KBV)}

KBV merupakan penyempurnaan dari Resource-Based View (RBV) dan Market-Based View (MBV). KBV menganggap pengetahuan sebagai sumber daya yang sangat strategik bagi perusahaan. Munculnya pandangan mengenai pengetahuan sebagai sumber daya perusahaan yang sangat strategik didasarkan oleh kenyataan bahwa pengetahuan dapat memenuhi kriteria sebagai sumber daya strategik yang dapat digunakan untuk mengembangkan daya saing perusahaan. Adapun syaratnya adalah 1) bernilai, 2) langka, 3) sukar ditiru pesaing, 4) tidak dapat digantikan (Sangkala, 2006). Oleh karena pengetahuan memenuhi kriteria tersebut, maka pengetahuan dipandang sebagai sumber daya yang bersifat strategik. Pengetahuan dianggap aset bagi perusahaan. Pandangan tersebut mengakibatkan munculnya pemahaman bahwa aset yang berupa pengetahuan tersebut apabila dikelola dengan baik dapat meningkatkan kinerja perusahaan. Kesuksesan perusahaan ditentukan oleh kemampuannya mentransformasikan pengetahuannya dan mengaplikasikannya ke dalam kegiatan yang bersifat strategik. Pengakuan pengetahuan sebagai aset strategik mengakibatkan pengetahuan perlu dikontrol, dikelola, dirasinalisasi, dan dikalkulasi. Selanjutnya pemahaman ini digunakan untuk memahami keberadaan Intellectual Capital (Sangkala, 2006). 


\section{Management Statement Disclosure (MSD)}

Dewasa ini kebutuhan akan informasi laporan keuangan secara menyeluruh semakin dibutuhkan oleh para stakeholder, terutama investor. Terbukti hasil dari beberapa penelitian menunjukkan bahwa semakin banyak voluntary disclosure perusahaan, maka persepsi pasar akan nilai perusahaan semakin meningkat. Demikian juga dengan pengungkapan laporan manajemen (MSD). Keberadaan MSD saja sudah menimbulkan nilai lebih, apalagi apabila komponen atau item yang disampaikan semakin banyak. Di Indonesia saat ini, masih sedikit perusahaan publik yang menyampaikan laporan manajemen. Isi dari laporan manajemen dapat berbeda antara satu perusahaan dengan perusahaan yang lain. Namun umumnya terdiri dari forecasting posisi keuangan dan pengungkapan untuk rencana strategis manajemen untuk jangka 1 (satu) periode ke depan. Pengukuran MSD menggunakan content analysis dengan melihat komponen-komponen yang diungkapkan oleh pihak direksi maupun dewan komisaris. Komponen-komponen tersebut meliputi operasional usaha, sosial, lingkungan hidup, keuangan, corporate governance, standar internasional, peningkatan sumber daya manusia, keselamatan kerja, strategi, dan prospek usaha.

\section{Intellectual Capital Disclosure (ICD)}

Beberapa definisi IC (Firer, 2003), IC merupakan kekayaan perusahaan yang merupakan kekuatan dibalik penciptaan kesejahteraan perusahaan. Komponen IC-nya meliputi : Phisical Capital, Human Capital, dan Structural Capital. IC merupakan sumber daya unik milik peusahaan yang berbeda yang dapat menjadi keunggulan bersaing perusahaan untuk menjamin kelangsungan hidup perusahaan (Chen, 2005). Komponen IC-nya meliputi : Capital Employed, Human Capital, dan Structural Capital. Pengukuran dilakukan dengan melihat ada tidaknya IC Disclosure di dalam annual report, mengacu penelitian Sveiby (dalam Purnomosidhi, 2006 dalam Suhardjanto dan Wardhani, 2010). Untuk menghitung IC Disclosure menggunakan model dummy, yaitu jika suatu item dalam kategori diungkapkan maka diberi nilai 1, dan nilai 0 jika tidak diungkapkan.

\section{Corporate Social Responsibility Disclosure (CSRD)}

Edvinson (1997) menyatakan bahwa CSR adalah kumpulan kewajiban perusahaan untuk melindungi dan memajukan masyarakat sekitar perusahaan berada. Ardana (2008) menyatakan bahwa tanggung jawab sosial perusahaan merupakan komitmen dan kemampuan dunia usaha untuk dapat melaksanakan hak dan kewajiban sosial terhadap lingkungan sosialnya sebagai kerangka menciptakan masyarakat peduli dan kemitraan. Pertanggungjawaban sosial biasanya diungkapkan perusahaan di sustainability reporting, yang berisi kebijakan ekonomi perusahaan, kegiatan pemberdayaan lingkungan dan sosial, pengaruh kinerja organisasi dan produknya terhadap pengembangan perusahaan yang berkelanjutan (Anggraini, 2006). Adanya pengungkapan CSR sebagai akibat dari tuntutan masyarakat karena biasanya perusahaan fokus dalam usaha memperoleh laba, dan melupakan tanggung jawab sosialnya kepada masyarakat. Anggraini (2006) menyampaikan bahwa terdapat 3 kategori CSR : 1) kinerja ekonomi, 2) kinerja lingkungan dan 3) kinerja sosial.

Untuk mengukur CSR digunakan CSR index (CSRI) yang merupakan luas pengungkapan relatif setiap perusahaan sampel atas pengungkapan sosial yang dilakukannya (Restuningdiah, 2011). CSRI menggunakan 
ukuran GRI G4 yang dikeluarkan oleh GRI. Untuk menghitung CSRI pada dasarnya menggunakan model dummy, yaitu jika suatu item dalam kategori diungkapkan maka diberi nilai 1, dan nilai 0 jika tidak diungkapkan.

\section{Nilai Perusahaan}

Nilai pasar merupakan hasil dari persepsi masyarakat terhadap kondisi perusahaan dan dalam usahanya memperoleh laba (Imaningati, 2009). Nilai pasar terwujud dari aset konvensional yang dapat dilihat di laporan keuangan, aset intelektual yang tersirat dalam laporan keuangan, dan kompetensi yang dimiliki oleh perusahaan yang tidak dapat dilihat di laporan keuangan. Nilai perusahaan juga tercermin dari tingkat apresiasi investor dan masyarakat atas kemampuan perusahaan menghasilkan laba. Oleh karenanya dalam penelitian ini menggunakan rasio pasar Price Earnings Ratio (PER), yang menunjukkan seberapa besar investor menilai perusahaan. PER lebih disukai investor, karena PER menunjukkan over value atau under value dari suatu perusahaan.

$$
\text { PER }=\frac{\text { harga saham per lembar saham }}{\text { laba per lembar saham }}
$$

\section{PENGEMBANGAN HIPOTESIS}

\section{Pengaruh Variabel MSD terhadap Nilai perusahaan}

Kebutuhan akan informasi yang lebih banyak bagi investor untuk pengambilan keputusan, terutama informasi mengenai hasil pelaksanaan strategi manajemen 1 periode yang lalu dan juga rencana strategi yang akan diterapkan oleh manajemen perusahaan 1 periode mendatang, telah mendorong perusahaan-perusahaan yang telah public untuk rutin menerbitkan laporan manajemen (management statement) (Cheung, 2012). Keberadaan laporan ini saja sudah menimbulkan persepsi “baik” bagi investor, bahwa manajemen perusahaan tersebut dapat diandalkan. Hal ini mendorong investor tertarik untuk membeli saham perusahaan. Disisi lain, adanya pengungkapan management statement, seolah itu merupakan kontrak kerja antara manajemen dengan stakeholder. Sehingga demi nama baik, manajemen akan berusaha keras mewujudkannya. Efeknya adalah peningkatan kegiatan operasional yang kemudian mengakibatkan peningkatan laba. Peningkatan laba yang diiringi dengan peningkatan harga saham (karena penawaran tetap sementara permintaan meningkat) menyebabkan nilai perusahaan yang diukur dengan PER meningkat.

\section{Hipotesis 1: Management statement disclosure berpengaruh positif terhadap nilai perusahaan.}

\section{Pengaruh Variabel ICD terhadap Nilai Perusahaan}

Ketika perusahaan pada posisi mempunyai kemampuan semakin tinggi dalam mengelola aset dan ekuitas perusahaan, mengelola SDM-nya dan juga kemampuan meningkatkan kompetensi dan keunggulan kompetitifnya, maka kegiatan operasional perusahaan akan meningkat, sehingga laba juga meningkat, dalam posisi ekuitas tetap, maka kinerja keuangan akan mengalami peningkatan. Selanjutnya peningkatan ini yang juga berarti peningkatan laba, akan menaikkan nilai perusahaan di mata investor karena laba per lembar sahamnya mengalami peningkatan (Sunarsih, 2012). 


\section{Hipotesis 2 : Intellectual capital disclosure berpengaruh positif terhadap nilai perusahaan.}

\section{Pengaruh Variabel CSRD terhadap Nilai Perusahaan}

Perusahaan dapat menerapkan konsep CSR Disclosure sebagai salah satu strateginya untuk menarik perhatian para investor. Asumsinya berarti perusahaan tersebut semakin banyak informasinya yang didisclose, hal ini menunjukkan semakin banyak kiprah/andil perusahaan kepada masyarakat. Dampaknya akan meningkatkan kepercayaan masyarakat terhadap perusahaan dan loyalitas terhadap produknya. Hasilnya adalah penjualan meningkat, yang mengakibatkan peningkatan laba. Peningkatan laba dapat meningkatkan kinerja keuangan. Pemegang saham melakukan investasi untuk mendapatkan pengembalian uang yang mereka investasikan, dalam bentuk deviden (yang diambil dari laba yang dihasilkan). Dengan menggunakan informasi keuangan ini, investor dapat melihat tingkat pengembalian atas investasi yang diukur dengan membandingkan laba bersih terhadap ekuitas saham biasa (Bringham, 2001). Selanjutnya peningkatan laba juga akan meningkatkan PER sebagai ukuran nilai perusahaan dilihat dari persepsi pasar.

Hipotesis 3 : Corporate social responsibility disclosure berpengaruh positif terhadap nilai perusahaan.

\section{METODE PENELITIAN}

\section{Populasi dan Sampel}

Populasi dalam penelitian ini adalah perusahaan-perusahaan yang mengikuti Sustainability Reporting Award. Adapun sampel diambil dengan menggunakan metode purposive sampling dengan pengkriteriaan sebagai berikut :

1. Perusahaan yang mengikuti Sustainability Reporting Award tahun 2013 dan atau 2014.

2. Perusahan yang listing di BEI di tahun 2013 dan 2014.

3. Perusahaan yang memiliki data keuangan lengkap yang dibutuhkan dalam penelitian ini.

4. Perusahaan yang menggunakan pedoman GRI-G4 dalam menyajikan Sustainability Report-nya.

\section{Analisis Regresi Linier Berganda}

Analisis ini digunakan untuk menguji Pengaruh Management Statement Disclosure Intellectual Capital Disclosure dan Corporate Social Responsibility Disclosure terhadap Nilai Perusahaan. Adapun model regresinya adalah sebagai berikut :

$$
Y=a+\beta_{1} X_{1}+\beta_{2} X_{2}+\beta_{3} X_{3}+\varepsilon
$$

Dimana :

$\mathrm{Y}=$ Nilai Perusahaan

$a=$ Konstanta

$\beta_{1-4}=$ Koefisien regresi

$\mathrm{X}_{1}=$ Management Statement Disclosure (MSD)

$\mathrm{X}_{2}=$ Intellectual Capital Disclosure (ICD)

$\mathrm{X}_{3}=$ Corporate Social Responsibility Disclosure (CSRD) 


\section{HASIL DAN PEMBAHASAN}

\section{Hasil Uji Kebaikan Model}

Uji F

Uji F pada dasarnya menunjukkan apakah semua variabel independen berpengaruh secara simultan terhadap variabel dependen. Pengujian simultan mengandung arti bahwa pengujian dilakukan secara serentak atau bersama- sama pada seluruh variabel independen dengan tujuan untuk mengetahui apakah variabelvariabel independen secara bersama-sama mempengaruhi variabel dependen. Selain itu uji F mengandung arti untuk menguji kebaikan model regresi yang digunakan. Berdasarkan uji regresi linier berganda diperoleh nilai F hitung sebesar 3,440 dengan tingkat signifikansi 0,032. Hal ini mengindikasikan bahwa variabel independen dapat menjadi penjelas bagi variabel dependen. Dengan demikian nilai perusahaan dapat dijelaskan oleh variabel Management Statement Disclosure, IC Disclosure, dan CSR Disclosure.

\section{Koefisien determinasi $\left(\mathbf{R}^{\mathbf{2}}\right)$}

Nilai koefisien determinasi yang ditunjukkan dengan nilai Adjusted $R^{2}$ dari model regresi digunakan untuk mengetahui besarnya return saham pada periode $\mathrm{t}$ yang dapat dijelaskan oleh variabel-variabel independennya. Tabel $1 \mathrm{di}$ atas memperlihatkan bahwa koefisien determinasi menunjukkan nilai Adjusted $R^{2}$ sebesar 20,7\%. Hal ini berarti bahwa Management Statement Disclosure, IC Disclosure, dan CSR Disclosure mampu mempengaruhi nilai perusahaan sebesar $20,7 \%$. Sisanya sebesar $79,3 \%$ dipengaruhi oleh variabel lain diluar variabel yang digunakan dalam penelitian ini.

\section{Hasil Uji Hipotesis}

Tabel 2 menunjukkan hasil bahwa Management Statement Disclosure (MSD) berpengaruh negatif terhadap Nilai Perusahaan. Hasil ini berlawanan dengan hipotesis yang diduga menunjukkan pengaruh positif. Jika apa yang disampaikan di dalam MSD semakin banyak maka Nilai Perusahaan akan semakin turun. Hal ini dapat dijelaskan menggunakan Teori Sinyal. Bahwa apa yang dilaporkan oleh manajemen dapat memberikan sinyal positif maupun negatif bagi stakeholder untuk mengambil keputusan. Tahun 2014 nilai rupiah mulai mengalami penurunan terhadap nilai dollar. Pertengahan 2014 merambat turun dan akhir tahun mengalami penurunan pesat. Hal ini berefek pada aktivitas perusahaan. Pendapatan dan laba perusahaan mengalami penurunan dan akhirnya hal ini dapat dilihat di Laporan keuangan. Untuk menetralisir hal tersebut maka manajemen biasanya menyampaikan nilai baiknya/manfaat dari penurunan disisi lain. Dan hal inilah yang memberikan sinyal negatif bagi para investor akan kondisi keuangan perusahaan. Semakin banyak yang diungkapkan oleh manajemen, sebagai sinyal ada "sesuatu" yang harus diperbaiki, sehingga persepsi stakeholder terhadap kondisi keuangan perusahaan menurun. Penurunan persepsi ini tercermin di penurunan harga saham. Apabila penurunan harga saham ini cukup besar relatif dengan penurunan laba, maka Nilai Perusahaan yang diukur dengan PER akan menurun pula.

Intellectual Capital Disclosure (ICD) tidak berpengaruh pada Nilai Perusahaan. Hal ini dapat dipahami mengingat beberapa pendapat yang menyampaikan bahwa manajemen IC adalah urusan perusahaan yang 
tidak mempunyai efek langsung pada investor. Ketika manajemen IC memenuhi standar maka bagi investor itu sudah memenuhi syarat, dan kemudian tidak menjadi bahan pertimbangan untuk pengambilan keputusan. Perusahaan publik biasanya sudah memenuhi standar tersebut.

Corporate Social Responsibility Disclosure (CSRD) berpengaruh positif terhadap nilai perusahaan. Perusahaan yang selain memperhatikan usaha untuk memperoleh laba tapi juga mempunyai tanggung jawab terhadap masyarakat, akan memperoleh apresiasi lebih dari masyarakat. Apresiasi tersebut dapat terlihat dari semakin diminatinya saham perusahaan, yang berakibat naiknya harga saham perusahaan. Selain hal tersebut di atas, apresiasi masyarakat juga dapat terlihat di semakin diminatinya produk perusahaan. Efek dari hal tersebut adalah pendapatan perusahaan meningkat dan laba juga semakin meningkat. Peningkatan laba yang diiringi dengan peningkatan harga saham mengakibatkan kenaikan nilai perusahaan yang iukur dengan PER (Price Earning Ratio).

\section{SIMPULAN}

Dari hasil pengujian statistik dan pembahasan, dapat disimpulkan bahwa :

1. Management Statement Disclosure (MSD) berpengaruh negatif terhadap Nilai Perusahaan.

2. Intellectual Capital Disclosure (ICD) tidak berpengaruh terhadap Nilai Perusahaan.

3. Corporate Social Responsibility Disclosure (CSRD) berpengaruh positif terhadap Nilai Perusahaan.

\section{Keterbatasan}

Keterbatasan merupakan suatu hal permasalahan yang ditemui saat melakukan penelitian, namun tidak dapat diperbaiki karena keterbatasan peneliti. Adapun keterbatasan dari penelitian ini adalah sedikitnya sampel penelitian yang dapat diperoleh. Hal ini terjadi karena penyesuaian yang dilakukan oleh peneliti dalam mengukur CSRD, dari menggunakan GRI-3 menjadi GRI-4 dengan alasan menggunakan alat ukur terbaru. Padahal baru sedikit perusahaan publik yang menggunakan GRI-4.

Selain hal tersebut, ditemui juga hasil Adjusted $R$ Square hanya menunjukkan 20,7\%, yang berarti masih banyak variabel lain yang mempengaruhi Nilai Perusahaan yang tidak diteliti dalam penelitian ini.

\section{Saran}

Walaupun saat penelitian ini dilakukan, perusahaan yang menggunakan GRI-4 masih sedikit, dan efeknya pada sampel yang sedikit, namun peneliti tetap menyarankan untuk penelitian selanjutnya tetap menggunakan GRI-4. Dengan harapan dimasa yang akan datang, perusahaan yang menggunakan GRI-4 semakin banyak.

Model perlu diperbaiki dengan menambah variabel independen. Karena dalam penelitian ini variabel independen semuanya merupakan variabel Disclosure, maka untuk penelitian selanjutnya peneliti menyarankan menggunakan variabel Disclosure lainnya. Contoh menggunakan variabel Good Corporate Governance Disclosure (GCGD). 


\section{Implikasi Manajerial}

Bagi perusahaan publik, mengingat CSRD ternyata berpengaruh positif pada Nilai Perusahaan, maka diharapkan benar-benar berusaha semakin banyak memenuhi kriteria yang ada di GRI-4 yang terbaru. Selain hal tersebut, mengingat MSD berpengaruh negatif, maka diharapkan manajemen perusahaan benar-benar harus berhati-hati dalam memberikan statement-nya.

\section{DAFTAR PUSTAKA}

Brigham, Eugene F and Joel F. Houston. Financial Management II. Jakarta : Salemba Empat, 2001.

Salvatore, Dominick. Managerial Economic : Managerial Economic in Global Economic (5 ${ }^{\text {th }}$ ed.). Jakarta, 2005.

Husnan, Suad dan Enny Pudjiastuti. Financial Management. Yogyakarta : UPP AMP YKPN, 2004.

Keown, Arthur J, John D. Martin, Petty J. William, and David F. Scott, Jr. Financial Management (9 ${ }^{\text {th }}$ ed). Jakarta : Gramedia, 2004.

Bringham, Eugene F and Louis C. Gapenski. Intermediate Finance Management ( $5^{\text {th }}$ ed.). Harbor Drive : The Dryden Press, 1996.

Wright J, J. George, R. Wellins, and W. Byham. Human Resources and Sustained Competitive Advantage, A Resource-Based Perspective. International Journal of Human Resource Management Vol. 5 No. 2 (1994) : 301-326.

Harahap, Sofyan Syafri. Crisis Analysis of Financial Reporting. Jakarta : PT. Raja Grafindo Persada, 2004.

Sawarjuwono, T. and A.P. Kadir. Intellectual Capital : Recognition, Measurement, and Reporting (Library Research). Journal of Accountancy and Financial Vol. 5, No. 1 (2003) : 35-57.

Ikatan Akuntan Indonesia. Standar Akuntansi Keuangan. Jakarta : Salemba Empat, Juni 2012.

Chen, M. C, S. J. Cheng, and Y. Hwang. An Empirical Investigation of the Relationship Between Intellectual Capital and Firm's Market Value and Financial Performance. Journal of Intellectual Capital Vol. 6 No. 2 (2005) : 159-176.

Williams, S,M. Is Intellectual Capital Performance and Disclosure Practice Related? Journal of Intellectual Capital Vol 2, No. 3 (2001).

Ghozali, Imam. Aplikasi Analisis Multivariate dengan Program SPSS. Semarang : Badan Penerbit Universitas Diponegoro, 2006.

Pulic, A. VAIC ${ }^{\mathrm{TM}}$ An Accounting Tool for IC Management. International Journal Technology Management 20 (5/6/8) (2000) : 702-714.

Ulum, Ihyaul. Intellectual Capital Performance, Banking Sector in Indonesia. Journal of Accounting and Financial Vol. 10 No. 2 November (2008) : 77-84.

Kuryanto, Benny dan Muchamad Syafrudin. The Influence of Intellectual Capital to Financial Performance. Simposium Nasional Akuntansi Il, Pontianak (2008).

Yuniasih, Ni Wayan, Dewa Gede Wirama and I Dewa Nyoman Badera. The Influence of Intellectual Capital to Corporate Market Performance, Empirical Study in Financial Corporation. Economic Faculty Udayana 
University (2010).

Solokhah, Badingatus, Abdul Rohman and Wahyu Meiranto. Intellectual Capital Implication to Financial Performance, Growth and Market Value, Empirical Study With Simplistic Specification. Accounting National Simposium XIII, Purwokerto (2010).

Firer, S. and S. M. Williams. (2003), Intellectual Capital and Traditional Measures of Corporate Performance. Journal of Intellectual Capital Vol. 4 No. 3 (2003) : 338-360.

Juniarti and Agnes Andriyani Sentosa. The Influence of GCG, Voluntary Disclosure to Debt Cost. Journal of Accountancy and Financial. Vol. 11 No. 2 November (2009) : 88-100.

Rustriarini, Ni Wayan. The Influence of Corporate Governance to Relationship Between Corporate Social responsibility and Corporate Value. Accountancy National XIII Simposium (2010).

Nurlela, Rika and Islahuddin. The Influence of Corporate Social Responsibility to the Firm Value with Management Ownership Percentage as the Moderating Variable. Universitas Syah Kuala (2006).

Sangkala. Intellectual Capital Management, New Strategy to Build Corporate Competitive Advantage. Jakarta : Yapensi, 2006.

Imaningati, Sri. The Influence of Intellectual Capital to Business Performance. Jurnal Prestasi Vol. 5 No. 2 Semarang (2009).

Susanto, A.B. Resource- Based vs Market-Based. Executive No. 333, May (2007) : 24-25.

Santoso, Grace. Market Reaction to GCG Index Disclosure, Big Ten and Non Big Ten. Journal of Economic and Business, Economic Faculty, Unika Widya Mandala, Surabaya (2008).

Pulic, A. Basic Information on VAIC ${ }^{\text {TM }}$, www.vaic-on.net (1999).

Bontis, Nick. Assessing Knowledge Assets : A Review of The Models Used to Measure Intellectual Capital. International Journal of Management Review Vol. 3, Issue, March (2001) : 41-60.

Edvinson and Malone. Intellectual Capital : Realizing Your Company's True Value by Finding its Hidden Brain Power. Journal of Intellectual Capital (1997).

Ardana, I Komang. CSR in Practic in Indonesia. Jakarta : PT. Elex Media Komputindo.

Anggraini, Fr. and Reni Retno. Social Information Disclosure and The factors that Influence Social Information Disclosure in The Annual Report. Accountancy National Simposium IX, Agustus, Padang (2006).

Sulistyo, Heru. The Influence of Reporting Social responsibility to Long Term Firm Performance. EKOBIS Vol. 9 No.1 (2008).

Restuningdiah, Nurika. Income Smoothing to Market Reaction with GCG Mechanism and CSR Disclosure. Journal of Management and Business Vol. 3, No. 3 (2011) : 241-260.

Sunarsih, Ni Made dan Ni Putu Yuria Mendra. The Influence of Intellectual Capital to Firm Value with Financial Performance as Intervening variabel. Accountancy National Symposium XV, Banjarmasin (2012).

Buskirk, Andrew Van, Zalm, Bozanic, Roulstone. Management Earnings Forecasts and Forward-Looking Statement. The Ohio State University, Fisher College of Business, 2100, Neil Avenue, Columbus, OH 43210, April 2013. Mohamed Ali B dan A. Habib. The Impact of ICD on Cost of Equity Capital, A Case of French Firm. Journal of Economic, Finance, and Administration Science, Elseiver Doyua, SCl, 18 (34) (2013) : 45-53. 
Li, J. Pike, Hanifa R. Intellectual Capital Disclosure and Corporate Governance Structure in UK Firms. Accounting and Bussines Research 38 (20) (2008) : 137-159.

Cheung, Pauline, Horace Ho, and Kin Chau. Intellectual Disclosure and Initial Public Offerings : Evidence from Hongkong. Journal of Applied and Business Research JAEBR, 2(2) (2012) : 56-68.

Suhardjanto, Djoko dan Mary Wardhani. Pengaruh Organizational Learning dan IT Capability terhadap Financial Performance, dan Pengaruh Tidak Langsung Melalui IT Capability. Jurnal Akuntansi dan Auditing Indonesia. Vol. 14 No. 1 Juni (2010) : 81-93. 


\section{LAMPIRAN}

\section{Statistik Deskriptif}

Tabel 1

Uji Kebaikan Model Dengan Koefisien Determinasi

\begin{tabular}{|c|c|c|c|c|}
\hline Model & $\mathrm{R}$ & R Square & $\begin{array}{l}\text { Adjusted } R \\
\text { Square }\end{array}$ & $\begin{array}{c}\text { Standard Error of the } \\
\text { Estimate }\end{array}$ \\
\hline 1 & 0,541 & 0,292 & 0,207 & 7,87128 \\
\hline
\end{tabular}

Sumber : Lampiran 5

Tabel. 2

Hasil Uji Hipotesis

\begin{tabular}{|c|c|c|c|c|}
\hline & Variabel & $\begin{array}{l}\text { Unstandardized } \\
\text { Coefficients (B) }\end{array}$ & Sig. & Keterangan \\
\hline Konstanta & & 7.597 & & \\
\hline $\mathrm{X}_{1}$ & MSD & $-19,279$ & 0,009 & $\begin{array}{c}\text { Berpengaruh, arah } \\
\text { Berbeda }\end{array}$ \\
\hline$x_{2}$ & ICD & 0,224 & 0,784 & Tidak berpengaruh \\
\hline$x_{3}$ & CSRD & 25,031 & 0,032 & Berpengaruh, arah sama \\
\hline
\end{tabular}

Sumber : Lampiran 6

\begin{tabular}{|c|c|c|c|c|c|}
\hline \multicolumn{6}{|c|}{ Descriptive Statistics } \\
\hline & $\mathrm{N}$ & Minimum & Maximum & Mean & Std. Deviation \\
\hline CSR_Disc & 29 & .50 & .97 & .6634 & .14321 \\
\hline IC_DisC & 29 & 10.00 & 17.00 & 13.6207 & 1.87871 \\
\hline MS_Disc & 29 & .00 & 1.00 & .7345 & .22721 \\
\hline NP & 29 & -10.68 & 34.88 & 13.0934 & 8.84051 \\
\hline Valid N (listwise) & 29 & & & & \\
\hline
\end{tabular}


Uji Normalitas

\section{Normal P-P Plot of Regression Standardized Residual}

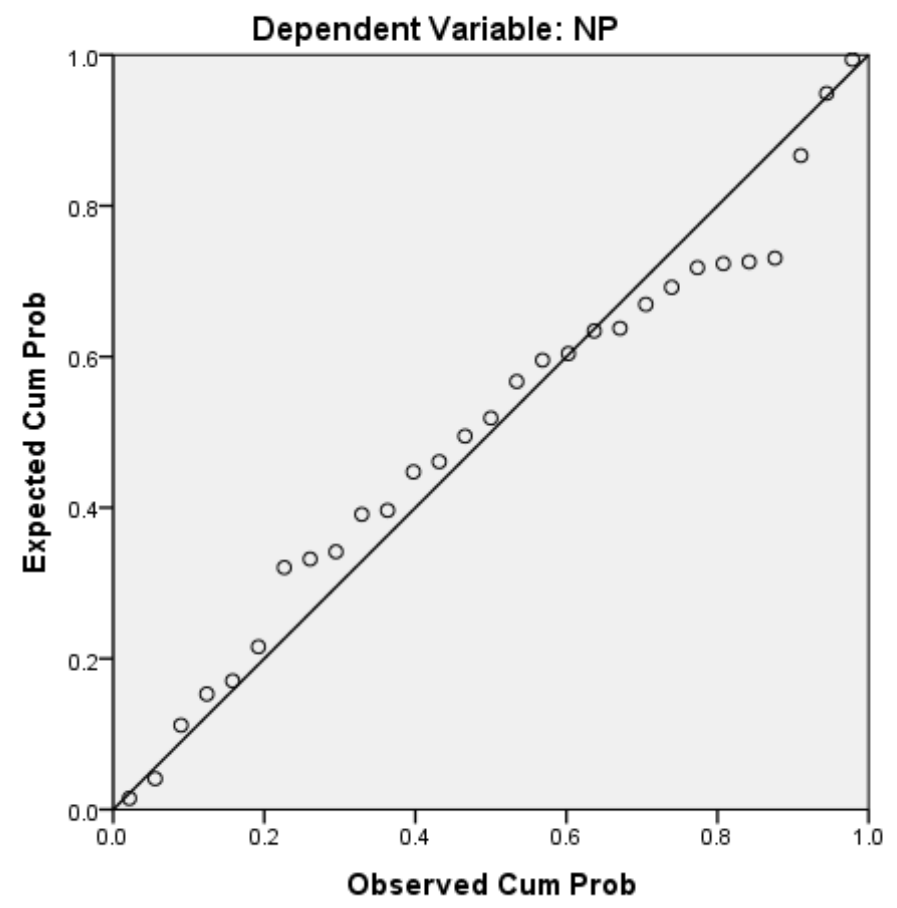

One-Sample Kolmogorov-Smirnov Test

\begin{tabular}{llr}
\hline & & $\begin{array}{r}\text { Unstandardized } \\
\text { Residual }\end{array}$ \\
\hline $\mathrm{N}$ & Mean & 29 \\
Normal Parameters & .0000000 \\
& Std. Deviation & 7.43766068 \\
& Absolute & .154 \\
Most Extreme Differences & Positive & .154 \\
& Negative & -.104 \\
Kolmogorov-Smirnov Z & & .830 \\
Asymp. Sig. (2-tailed) & & .496 \\
\hline a. Test distribution is Normal. & & \\
b. Calculated from data. &
\end{tabular}




\section{Uji Multikolonieritas}

\begin{tabular}{|c|c|c|c|c|c|c|c|c|}
\hline \multicolumn{9}{|c|}{ Coefficients $^{a}$} \\
\hline \multirow{3}{*}{\multicolumn{2}{|c|}{ Model }} & \multirow{2}{*}{\multicolumn{2}{|c|}{$\begin{array}{c}\text { Unstandardized } \\
\text { Coefficients }\end{array}$}} & \multirow{3}{*}{$\begin{array}{l}\text { Standardized } \\
\text { Coefficients } \\
\text { Beta }\end{array}$} & \multirow{3}{*}{$\mathrm{t}$} & \multirow{3}{*}{ Sig. } & \multirow{2}{*}{\multicolumn{2}{|c|}{ Collinearity Statistics }} \\
\hline & & & & & & & & \\
\hline & & B & Std. Error & & & & Tolerance & VIF \\
\hline \multirow{4}{*}{1} & (Constant) & 7.597 & 14.502 & & .524 & .605 & & \\
\hline & CSR_Disc & 25.031 & 11.052 & .405 & 2.265 & .032 & .883 & 1.132 \\
\hline & IC_Disc & .224 & .808 & .048 & .277 & .784 & .959 & 1.042 \\
\hline & MS_DisC & -19.279 & 6.829 & -.496 & -2.823 & .009 & .919 & 1.088 \\
\hline
\end{tabular}

a. Dependent Variable: NP

Uji Heteroskedastisitas

Coefficients $^{\mathrm{a}}$

\begin{tabular}{|c|c|c|c|c|c|c|c|c|}
\hline \multirow{2}{*}{\multicolumn{2}{|c|}{ Model }} & \multicolumn{2}{|c|}{$\begin{array}{c}\text { Unstandardized } \\
\text { Coefficients }\end{array}$} & \multirow{2}{*}{$\begin{array}{c}\text { Standardized } \\
\text { Coefficients } \\
\text { Beta }\end{array}$} & \multirow{2}{*}{$\mathrm{t}$} & \multirow{2}{*}{ Sig. } & \multicolumn{2}{|c|}{ Collinearity Statistics } \\
\hline & & B & Std. Error & & & & Tolerance & VIF \\
\hline \multirow{4}{*}{1} & (Constant) & -.710 & 9.389 & & -.076 & .940 & & \\
\hline & CSR_DisC & 2.150 & 7.155 & .062 & .300 & .766 & .883 & 1.132 \\
\hline & IC_DisC & .066 & .523 & .025 & .126 & .901 & .959 & 1.042 \\
\hline & MS_Disc & 5.185 & 4.421 & .236 & 1.173 & .252 & .919 & 1.088 \\
\hline
\end{tabular}

Uji F

Model Summary

\begin{tabular}{|c|c|c|c|c|}
\hline Model & $\mathrm{R}$ & R Square & $\begin{array}{l}\text { Adjusted R } \\
\text { Square }\end{array}$ & $\begin{array}{l}\text { Std. Error of the } \\
\text { Estimate }\end{array}$ \\
\hline 1 & $.541^{\mathrm{a}}$ & .292 & .207 & 7.87128 \\
\hline
\end{tabular}

\begin{tabular}{|c|c|c|c|c|c|c|}
\hline \multicolumn{7}{|c|}{ ANOVA $^{a}$} \\
\hline Model & & Sum of Squares & df & Mean Square & $\mathrm{F}$ & Sig. \\
\hline \multirow{3}{*}{1} & Regression & 639.402 & 3 & 213.134 & 3.440 & $.032^{\mathrm{b}}$ \\
\hline & Residual & 1548.926 & 25 & 61.957 & & \\
\hline & Total & 2188.329 & 28 & & & \\
\hline
\end{tabular}

a. Dependent Variable: NP

b. Predictors: (Constant), MS_Disc, IC_Disc, CSR_DisC 
Uji t

\begin{tabular}{|c|c|c|c|c|c|c|c|c|}
\hline \multicolumn{9}{|c|}{ Coefficients $^{a}$} \\
\hline \multirow{2}{*}{\multicolumn{2}{|c|}{ Model }} & \multicolumn{2}{|c|}{ Unstandardized Coefficients } & \multirow{2}{*}{$\begin{array}{c}\text { Standardized } \\
\text { Coefficients } \\
\text { Beta }\end{array}$} & \multirow{2}{*}{$\mathrm{t}$} & \multirow{2}{*}{ Sig. } & \multicolumn{2}{|c|}{ Collinearity Statistics } \\
\hline & & B & Std. Error & & & & Tolerance & VIF \\
\hline \multirow{4}{*}{1} & (Constant) & 7.597 & 14.502 & & .524 & .605 & & \\
\hline & CSR_Disc & 25.031 & 11.052 & .405 & 2.265 & .032 & .883 & 1.132 \\
\hline & IC_Disc & .224 & .808 & .048 & .277 & .784 & .959 & 1.042 \\
\hline & MS_Disc & -19.279 & 6.829 & -.496 & -2.823 & .009 & .919 & 1.088 \\
\hline
\end{tabular}

a. Dependent Variable: NP 